\title{
Ontogenetic Changes in Meristic Measurements of Silver Carp and Bighead Carp
}

\author{
YU Hong-Xia, TANG Wen-Qiao*, LI Si-Fa \\ (Laboratory of Ichthyology, Shanghai Ocean University, Key Laboratory of Exploration and Utilization of Aquatic Genetic \\ Resources, Ministry of Education, Shanghai 200090, China)
}

\begin{abstract}
The study analyzed 30 exterior meristic characters for 255 silver and bighead carp samples of 1- to 5-year-old collected from the National Primary Breeding Farm at Laojianghe Lake at the Middle Reach of the Yangtze River. Multivariate analysis was performed. In silver carp, the Euclidean distance was the greatest between the 1-year-old group and other age groups. Silver carp individuals were correctly classified at $98.0 \%$ accuracy with a discriminant function established by discriminant analysis based on meristic measurements. Similarly, bighead carp had the greatest distance between 1- to 2-year-old group and other age groups. Individuals of bighead carp were correctly classified at $90.7 \%$ accuracy by the discrimination function. The data showed that morphological transformation occurred during the life history of silver and bighead carp development. Eighteen meristic measurements showed highly significant differences, while four showed a significant difference between the two silver carp groups. Ten parameters decreased, while twelve measurements increased during development. In bighead carp, fourteen parameters were significantly different, while three parameters were significantly different between the two groups. Twelve parameters were significantly decreased and another five were increased during development. The results suggest allometric growth should be taken into account when identifying species, analyzing population differences and establishing germplasm standards based on morphology.
\end{abstract}

Key words: Hypophthalmichthys molitrix; Aristichthys nobilis; Ontogeny; Morphology; Allometric growth; Yangtze River

\section{长江鲢、鳙个体发育过程中的表型变化}

\author{
于红霞, 唐文乔", 李思发 \\ （上海海洋大学 鱼类研究室，水产种质资源发掘与利用教育部重点实验室 上海 201306)
}

摘要: 采用多元分析方法, 对采自长江老江河国家级四大家鱼原种场 255 尾 1-5 龄鲢、鲭的 30 项形态度量 数据进行了分析。聚类分析显示, 鲢可明显地聚成欧氏距离相对较远的 1 龄组和 $2-5$ 龄组, 鳙也可聚成欧氏距离 较远的 1、2 龄组与 3-5 龄组。判别分析显示, 144 尾鲢个体对所聚类的两个组别的判别准确率高达 $98.0 \%, 111$ 尾鳙个体对所聚类的两个组别的判别准确率也达 $90.7 \%$ 。这表明, 在幼体向成体的发育过程中, 鲢和鳙在形态上 均存在着两个具有显著差异阶段。单因素方差分析显示, 鲢两个组别之间有 18 个参数差异极显著, 4 个差异显著, 其中 10 个显著或极显著地变小，12 个显著或极显著地变大。鳙两个组别间有极显著和显著差异的参数分别有 14 个和 3 个, 其中极显著或显著差异变小和变大的分别有 12 个和 5 个。这表明在鲢、鳙个体发育过程中, 分别有 73.3\%和 56.7\%的特征参数具有生长异速现象。因此, 在根据形态鉴别物种、分析种群差异、确立种质标准和作生 长退算时, 均应考虑所选用特征的生长异速现象。

关键词: 鲢; 鳙; 个体发育; 外部形态; 生长异速; 长江

中图分类号: Q959.468 文献标识码: A 文章编号: 0254-5853-(2010)02-0169-08

Silver carp (Hypophthalmichthys molitrix) and bighead carp (Aristichthys nobilis) have been major fresh

Received date: 2009-07-22; Accepted date: 2010-01-20

Foundation items: This work was supported by a grant from the National Natural Science Foundation of China (30630051); Aquaculture

E-Institute of Shanghai Universities (03E009); Shanghai Leading Academic Discipline Project（S30701）

${ }^{*}$ Corresponding author (通讯作者), E-mail: wqtang@shou.edu.cn

First author: YU Hong-Xia (1982-), female, graduate student; E-mail:yuhongxia2002@163.com

收稿日期：2009-07-22；接受日期：2010-01-20 
water aquaculture species since Tang Dynasty in China (Li et al, 1990). Since the success of artificial breeding of the four domesticated fishes during the 1950s, silver and bighead carp have been introduced to many countries world-wide (Schofield et al, 2005) and their farming yields were the highest in China and other countries ( $\mathrm{Li}$ et al, 1990; Schofield et al, 2005). As the primary natural germplasm resources these two species are found along the Yangtze River and their biological characteristics and resource status in the Yangtze River have been further studied (Liu et al, 1992; Chen et al, 1995; Liu et al, 1997; 2004; Qiu et al, 2002). In recent 30 years, natural resources of silver and bighead carp have been severely damaged by water pollution, construction and over-fishing. The frequent escape and release of cultivated population to the wild have also disturbed the natural gene pool of these species. Monitoring silver and bighead carp germplasm resources in the Yangtze River and their biological variations has become an important task for resources protection (Liu et al, 1992, Cao et al, 2008).

Morphological characteristics and development of silver and bighead carp have been studied in great detail (Li et al, 1989, 1990, 1995; Liu et al, 1992; Sun et al, 1992, Ding et al, 2003; Yu et al, 2009). Morphological standards of primary breeding stock have been proposed (Li et al, 1997). As allometry exists in fish growth (Osse et al, 1995), it is necessary to study morphometrics of these species at various ages during their life cycle in order to evaluate germplasm quality and establish standards. However, no report has evaluated morphological changes from juveniles to adults of these two species.

In order to clarify the trend of morphological changes during juvenile to adult development, we have compared meristic characteristics of silver carp and big head of different ages from the Laojianghe Primary Breeding Farm. This information is necessary for the Yangtze River germplasm evaluation and the formulation of morphological standards for these primary resources.

\section{Materials and Methods}

\subsection{Materials}

The National Laojianghe Primary Breeding Farm for the Four Domesticated Fishes $\left(29^{\circ} 35^{\prime} \mathrm{N}, 113^{\circ} 00\right.$

' E) is located in Jianli county, Hubei Province. The water body was formed naturally in 1901 as a remnant lake to the north bank of lower Jinjiang Section. In 1958, dams were constructed at the entrance and exit of the water way, forming a narrow horseshoe lake of $22.5 \mathrm{~km}$ long, $1.1 \mathrm{~km}$ wide with a $49.4 \mathrm{~km}$ shoreline. Normally, when water level is $27.5 \mathrm{~m}$, the water surface area is $1840 \mathrm{~km}^{2}$, with the greatest depth of $19 \mathrm{~m}$ and average depth of $6 \mathrm{~m}$. The averaged annual rainfall of the lake is $1226 \mathrm{~mm}$ and 134 days, and the sunlight is $2004 \mathrm{~h}$ (Liu et al, 2002). In 1991, “The Four Domesticated Fish Natural Germplam Resources Ecological Reserve of the Yangtze Water System” was established by the Ministry of Agriculture to protect the fish population resource.

Samples were collected from the Primary Breeding Farm in January of 2008. One-year-old group were captured from the fry pond $\left(6.7 \mathrm{hm}^{2}\right)$ while other age groups were captured from the lake by net and picked at random with different sizes. Measurements of body length (accurate to $1 \mathrm{~cm}$ ) and weight (accurate to $1 \mathrm{~g}$ ) of each individual were taken on site. Photographs for each individual were taken from the left side by digital camera (Canon) at $1.2 \mathrm{~m}$ with visible scale. Intact scales (10-20 pieces) were taken from each individual and preserved in bags for age determination. Scales were submerged in water for 1-2 h, then cleaned and mounted between two slides. The slides were projected to screen for structure observation at 20 or $50 \times$ magnification. Age marks were determined as reported by Yu et al (2009). Ages, body length and weight of the fish were shown in Tab. 1 and Tab.2.

\subsection{Body measurement}

Digitized images of specimens were measured for 30 conventional and truss network measurements (Tab. 3). Conventional measurements include total length,

Tab. 1 Body length and weight of Silver Carp

\begin{tabular}{cccccc}
\hline \multirow{2}{*}{ Age group } & \multirow{2}{*}{$\begin{array}{c}\text { No. of } \\
\text { specimen }\end{array}$} & \multicolumn{2}{c}{ Body length (cm) } & \multicolumn{2}{c}{ Body weight (g) } \\
& Range & Mean & Range & Mean \\
\hline 1 & 49 & $130-220$ & 184.49 & $102-206$ & 168.47 \\
2 & 24 & $375-470$ & 430.43 & $540-1750$ & 1245.06 \\
3 & 21 & $360-580$ & 498.10 & $1240-3586$ & 2470.65 \\
4 & 34 & $460-600$ & 526.47 & $1478-4300$ & 3266.50 \\
5 & 16 & $520-690$ & 560.63 & $3012-4798$ & 3976.24 \\
\hline
\end{tabular}


Tab. 2 Body length and weight of Bighead Carp

\begin{tabular}{cccccc}
\hline \multirow{2}{*}{ Age group } & $\begin{array}{c}\text { No. of } \\
\text { specimen }\end{array}$ & \multicolumn{2}{c}{ Body length (cm) } & \multicolumn{2}{c}{ Body weight (g) } \\
& & Range & Mean & Range & Mean \\
\hline 1 & 32 & $18-29$ & 22.69 & $130-556$ & 284.50 \\
2 & 23 & $30-47$ & 37.33 & $632-2534$ & 1367.08 \\
3 & 37 & $41-62$ & 49.25 & $1240-5440$ & 2811.18 \\
4 & 15 & $44-70$ & 57.40 & $1478-7000$ & 4194.53 \\
5 & 4 & $68-78$ & 71.00 & $6000-10500$ & 7800.00 \\
\hline
\end{tabular}

head length, head depth, snout length, eye diameter, body depth, pectoral length, caudal peduncle length and depth. Ten morphological landmarks were used for truss network measurements, as shown in Fig. 1 ( $\mathrm{Li}$ et al, 1990): tip snout, most anterior of scales on skull, origin of dorsal fin, back end of dorsal fin base, dorsal origin of caudal fin, ventral origin of caudal fin, back end of anal fin base, origin of anal fin, origin of pelvic fin, origin of pectoral fin. Twenty one measurements were constructed from these 10 landmark points. All truss measurements were directly obtained from the digital images using computer software (accurate to $0.01 \mathrm{~mm}$ ).

\subsection{Data analysis}

Meristic measurements vary greatly in magnitude values. To weigh in measurements of smaller absolute values, snout length and eye diameter were standardized to head length and the rest of the measurements were standardized to total body length. All data were first tabulated with Microsoft Excel, and then analyzed with SPSS 11.0 (Yu et al, 2003).

Cluster analysis: Intergroup and mean intragroup Euclidean distances were first calculated, then

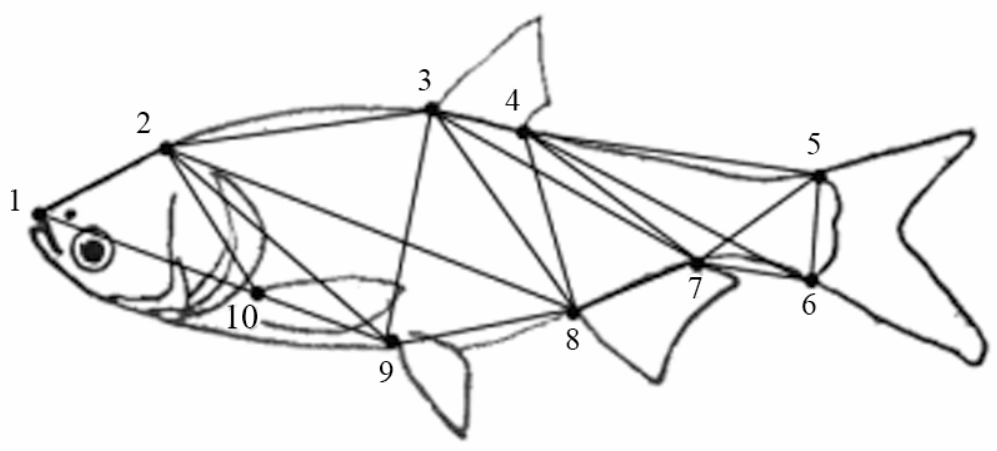

Fig. 1 Schematic measurement for truss network

1, Snout tip. 2, Most anterior of scales on skull. 3, Origin of dorsal fin. 4, Back end of dorsal fin base. 5, Dorsal origin of caudal fin. 6, Ventral origin of caudal fin. 7, Back end of anal fin base. 8,Origin of anal fin. 9, Origin of pelvic fin. 10, Origin of pectoral fin.

Note: Truss parameter measurement is the distance between two of the 10 landmark points. Forexample, D1-2 denotes the distance between landmark points 1 and 2.

Tab. 3 Morphometric characters

\begin{tabular}{ll||ll||ll}
\hline Code & Measurement & Code & Measurement & Code & Measurement \\
\hline 1 & Total length & 2 & Head length & 3 & Snout length \\
4 & Eye diameter & 5 & Body depth & 6 & Pectoral fin length \\
7 & Length of caudal peduncle & 8 & Depth of caudal peduncle & 9 & Depth of head \\
10 & $\mathrm{D}_{1-2}$ & 11 & $\mathrm{D}_{2-3}$ & 12 & $\mathrm{D}_{3-4}$ \\
13 & $\mathrm{D}_{4-5}$ & 14 & $\mathrm{D}_{5-6}$ & 15 & $\mathrm{D}_{6-7}$ \\
16 & $\mathrm{D}_{7-8}$ & 17 & $\mathrm{D}_{8-9}$ & 18 & $\mathrm{D}_{9-1}$ \\
19 & $\mathrm{D}_{1-10}$ & 20 & $\mathrm{D}_{2-10}$ & 21 & $\mathrm{D}_{9-10}$ \\
22 & $\mathrm{D}_{2-9}$ & 23 & $\mathrm{D}_{3-8}$ & 24 & $\mathrm{D}_{4-7}$ \\
25 & $\mathrm{D}_{2-8}$ & 26 & $\mathrm{D}_{3-9}$ & 27 & $\mathrm{D}_{3-7}$ \\
28 & $\mathrm{D}_{4-8}$ & 29 & $\mathrm{D}_{6-7}$ & 30 & $\mathrm{D}_{4-5}$ \\
\hline
\end{tabular}


hierarchical cluster analysis was performed using minimum distance method to create dendrograms (Zhang et al, 1982).

Discriminant analysis: Discriminant functions were established using stepwise method, and samples were categorized based on the discriminant functions. Accuracy of the functions was then tested ( $\mathrm{Li}$ et al, 1998).

One way analysis of variance was used to test differences between groups.

\section{Results}

\subsection{Clustering analysis}

Euclidean distances between groups were calculated from standardized conventional and truss measurements for silver and bighead carps (Tab. 4, 5). Hierarchical clustering dendrograms are shown in Fig. 2. Five age groups formed 3 clusters, in which cluster I contained only 1-year-old group, cluster II contained 2- and 3-year old-group, while cluster III contained 4- and 5-year-old group. However, distance between clusters II and III was relatively short. Bighead carp also formed 3 clusters, where cluster I contained 1- and 2-year-old-group, cluster II contained 3- and 4-year-old-group, while cluster III contained 5-year-old. Distance between clusters I and II was short too. These results suggest the development of these two species can be divided in two morphologically distinct stages.

\subsection{Discriminant analysis}

Discriminant functions were established stepwise for all clusters of silver carp and discriminant tests were performed. Results were shown in Tab. 6. The accuracy for cluster I discrimination was $98.0 \%$. But the accuracy for cluster II and III was $64.4 \%$ and $78.0 \%$. A high rate of misidentification occurred for individuals in clusters II and III. These results are consistent with the short distance between the two clusters. When clusters II and III are combined, where one-year-old group is still in cluster I, and the other age groups in cluster II, the discrimination accuracy is $98 \%$ (Tab. 7).

Similarly, discriminant analysis for bighead carp was highly accurate for cluster I, and less accurate for clusters II and III. After combining clusters II and III, discrimination accuracy was increased (Tab. 8). The
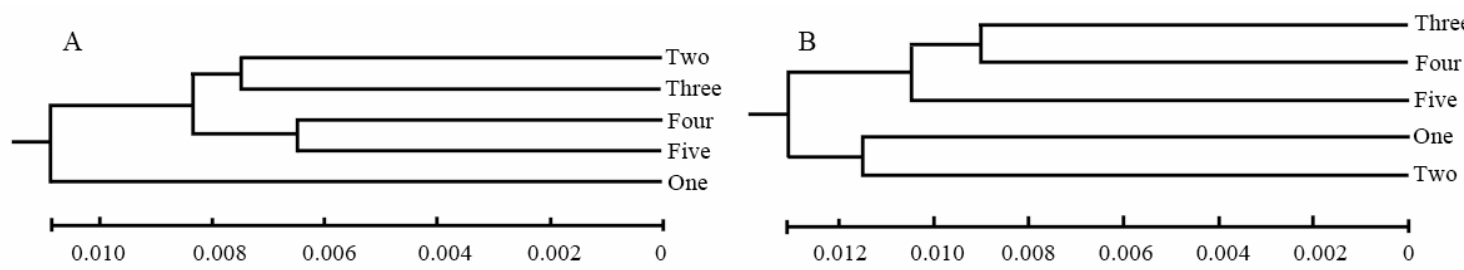

Fig. 2 Dendrogram of different age groups

A. Silver Carp; B. Bighead Carp.

Tab. 4 Euclidean distances among age groups of silver carp

\begin{tabular}{ccccccc}
\hline Age group & No. of specimen & 1 & 2 & 3 & 4 & 5 \\
\hline 1 & 49 & 0.0000 & & & & \\
2 & 24 & 0.0168 & 0.0000 & & & \\
3 & 21 & 0.0200 & 0.0146 & 0.0000 & & \\
4 & 34 & 0.0214 & 0.0159 & 0.0131 & 0.0000 & \\
5 & 16 & 0.0293 & 0.0202 & 0.0179 & 0.0180 & 0.0000 \\
\hline \multicolumn{2}{l}{ Average distance within group } & 0.0087 & 0.0134 & 0.0127 & 0.0134 & 0.0185 \\
\hline
\end{tabular}

Tab. 5 Euclidean distances among age groups of bighead carp

\begin{tabular}{ccccccc}
\hline Age group & No. of specimen & 1 & 2 & 3 & 4 & 5 \\
\hline 1 & 32 & 0.0000 & & & & \\
2 & 23 & 0.0225 & 0.0000 & & & \\
3 & 37 & 0.0266 & 0.0227 & 0.0000 & & \\
4 & 15 & 0.0282 & 0.0233 & 0.0182 & 0.0000 & \\
5 & 4 & 0.0290 & 0.0268 & 0.0213 & 0.0211 & 0.0000 \\
\hline Average distance within group & 0.0222 & 0.0214 & 0.0162 & 0.0201 & 0.0203 \\
\hline
\end{tabular}


Tab. 6 Discrimination among three clusters of silver carp

\begin{tabular}{lccccc}
\hline \multirow{2}{*}{ Group } & No. of specimen & Accuracy (\%) & \multicolumn{2}{c}{ No. of specimen assigned by discriminant analysis } \\
\cline { 4 - 6 } & 49 & 98.0 & Group I & Group II & Group III \\
\hline Group I & 45 & 64.4 & 48 & 1 & 0 \\
Group II & 50 & 78.0 & 2 & 29 & 14 \\
Group III & 144 & 80.56 & 50 & 11 & 39 \\
\hline Total & & & 0 & 41 & 53 \\
\hline
\end{tabular}

Tab. 7 Discrimination between two combined clusters of silver carp

\begin{tabular}{lcccc}
\hline \multirow{2}{*}{ Group } & No. of specimen & Accuracy (\%) & \multicolumn{2}{c}{ No. of specimen assigned by discriminant analysis } \\
\cline { 3 - 5 } & & & Group I & Group II \\
\hline Group I & 49 & 98.0 & 48 & 1 \\
Group II & 95 & 98.0 & 2 & 93 \\
\hline Total & 144 & 98.0 & 50 & 94 \\
\hline
\end{tabular}

Tab. 8 Discrimination between two combined clusters of bighead carp

\begin{tabular}{lcccc}
\hline \multirow{2}{*}{ Group } & No. of specimen & Accuracy (\%) & \multicolumn{2}{c}{ No. of specimen assigned by discriminant analysis } \\
\cline { 4 - 5 } & & & Group I & Group II \\
\hline Group I & 54 & 90.7 & 49 & 5 \\
Group II & 64 & 90.6 & 6 & 58 \\
\hline Total & 118 & 90.7 & 55 & 63 \\
\hline
\end{tabular}

discrimination accuracy for the two clusters was $90.7 \%$ and $90.6 \%$, respectively. The data suggest that silver and bighead carps have two morphologically distinguished developmental stages.

\subsection{One way analysis of variance}

One way ANOVA was carried out to determine whether two clusters were statistically different in any meristic measurement. Results were shown in Tab. 9 and 10.

Eighteen indices showed highly significant difference between the two stages of silver carp. Four indices showed significant difference, while only 8 indices showed no statistical difference between the two stages. Among them, ten indices (e.g. depth/body length, snout/head length) decreased during development, while 12 indices (e. g. pectoral fin length/body length) were significantly increased during development (Tab. 9).

Fourteen indices in bighead carp showed a high significant difference between the two clusters and 3 indices were significantly different, while the remaining thirteen indices were not different. Among these, twelve indices became smaller during development, while five indices increased during development (Tab. 10)

\section{Discussion}

\subsection{Developmental changes of silver and bighead}

carps

Morphological characteristics are crucial for species identification and germplasm determinations (Xie et al, 2003; Guo et al, 2004; Li et al, 2006; Qi et al, 2006; Zhao et al, 2007). However, some growth measurements were at different rates in fish, known as allometry (Osse et al, 1995). Fish body geometry changes along with development. To date, studies on geometric changes of silver and bighead carps were mainly focused on the development of hatchlings and fingerlings (Axel et al ,1990; Wan, 2004; Lin et al, 2006; Wang et al, 2008; Shan et al, 2009; Huysentruyt et al, 2009). Few studies have been done on the development these species from juvenile to adult (Lu, 2008).

Silver and bighead carp are fast growing, large freshwater species. The largest individuals can grow up to $40 \mathrm{~kg}$. Parents of these two species spawn in rapid water. Fingerlings and parents actively migrate to lakes or quiet regions of river for feeding. Silver carp reaches sexual maturity at 3 years of age. Bighead carps reaches sexual maturity at 4-5 years of age. The current studies analyzed conventional and truss measurements of these species from 1 to 5 years of age. Cluster analysis of meristic measurements suggests that silver carps can be divided into three clusters: 1-year-old cluster, 2- to 3 -year-old cluster and 4- to 5-year-old cluster. Bighead 
Tab. 9 Indices of significantly difference between two combined clusters of Silver Carps

\begin{tabular}{|c|c|c|c|c|}
\hline \multirow{2}{*}{ Character } & \multicolumn{2}{|c|}{ Mean values $(\mathrm{cm})$} & \multirow{2}{*}{$P$ Value } & \multirow{2}{*}{ Trend of change } \\
\hline & Cluster I & Cluster II & & \\
\hline Total length/Body length & $1.214 \pm 0.017$ & $1.177 \pm 0.026$ & 0.000 & decrease \\
\hline Snout length/Head length & $0.185 \pm 0.018$ & $0.150 \pm 0.024$ & 0.000 & decrease \\
\hline Eye diameter/Head length & $0.183 \pm 0.020$ & $0.132 \pm 0.020$ & 0.000 & decrease \\
\hline Body depth/Body length & $0.305 \pm 0.012$ & $0.282 \pm 0.012$ & 0.000 & decrease \\
\hline Depth of head/Body length & $0.247 \pm 0.010$ & $0.238 \pm 0.080$ & 0.000 & decrease \\
\hline $\mathrm{D}_{1-2} /$ Body length & $0.254 \pm 0.016$ & $0.233 \pm 0.090$ & 0.000 & decrease \\
\hline $\mathrm{D}_{9-10} /$ Body length & $0.208 \pm 0.014$ & $0.195 \pm 0.010$ & 0.000 & decrease \\
\hline $\mathrm{D}_{3-4} /$ Body length & $0.108 \pm 0.014$ & $0.103 \pm 0.011$ & 0.025 & decrease \\
\hline $\mathrm{D}_{5-6} /$ Body length & $0.126 \pm 0.008$ & $0.122 \pm 0.008$ & 0.025 & decrease \\
\hline $\mathrm{D}_{1-9} /$ Body length & $0.491 \pm 0.016$ & $0.485 \pm 0.013$ & 0.025 & decrease \\
\hline $\mathrm{D}_{2-3} /$ Body length & $0.291 \pm 0.015$ & $0.305 \pm 0.010$ & 0.000 & decrease \\
\hline $\mathrm{D}_{8-9} /$ Body length & $0.229 \pm 0.016$ & $0.243 \pm 0.014$ & 0.000 & increase \\
\hline $\mathrm{D}_{2-10} /$ Body length & $0.200 \pm 0.013$ & $0.206 \pm 0.016$ & 0.002 & increase \\
\hline $\mathrm{D}_{2-9} /$ Body length & $0.349 \pm 0.012$ & $0.354 \pm 0.010$ & 0.024 & increase \\
\hline Pectoral fin length/Body length & $0.203 \pm 0.088$ & $0.210 \pm 0.014$ & 0.010 & increase \\
\hline $\mathrm{D}_{3-8} /$ Body length & $0.299 \pm 0.013$ & $0.317 \pm 0.010$ & 0.000 & increase \\
\hline $\mathrm{D}_{4-7} /$ Body length & $0.258 \pm 0.016$ & $0.273 \pm 0.013$ & 0.000 & increase \\
\hline $\mathrm{D}_{2-8} /$ Body length & $0.518 \pm 0.017$ & $0.533 \pm 0.015$ & 0.000 & increase \\
\hline $\mathrm{D}_{3-9} /$ Body length & $0.264 \pm 0.015$ & $0.290 \pm 0.009$ & 0.000 & increase \\
\hline $\mathrm{D}_{3-7} /$ Body length & $0.358 \pm 0.016$ & $0.367 \pm 0.012$ & 0.000 & increase \\
\hline $\mathrm{D}_{4-8} /$ Body length & $0.219 \pm 0.012$ & $0.240 \pm 0.010$ & 0.000 & increase \\
\hline $\mathrm{D}_{6-7} /$ Body length & $0.364 \pm 0.022$ & $0.374 \pm 0.018$ & 0.010 & increase \\
\hline
\end{tabular}

Tab. 10 Indices of significantly difference between two combined clusters of Bighead Carps

\begin{tabular}{lcccc}
\hline \multirow{2}{*}{ Character } & \multicolumn{2}{c}{ Mean values (cm) } & Value of $P$ & Trend of change \\
\cline { 2 - 4 } & Cluster I & Cluster II & & decease \\
\hline Total length/Body length & $1.191 \pm 0.053$ & $1.171 \pm 0.034$ & 0.009 & decrease \\
Total length/Body length & $0.387 \pm 0.016$ & $0.371 \pm 0.016$ & 0.000 & decrease \\
Eye diameter/ Head length & $0.141 \pm 0.017$ & $0.116 \pm 0.015$ & 0.000 & decrease \\
Body depth/Body length & $0.296 \pm 0.019$ & $0.285 \pm 0.016$ & 0.000 & decrease \\
D1-2/Body length & $0.294 \pm 0.016$ & $0.285 \pm 0.017$ & 0.002 & decrease \\
D7-8/ Body length & $0.152 \pm 0.017$ & $0.142 \pm 0.104$ & 0.002 & decrease \\
D1-10/Body length & $0.335 \pm 0.016$ & $0.322 \pm 0.016$ & 0.000 & decrease \\
$\begin{array}{l}\text { D2-10/Body length } \\
\text { D2-9/Body length }\end{array}$ & $0.231 \pm 0.016$ & $0.216 \pm 0.012$ & 0.000 & decrease \\
$\begin{array}{l}\text { D3-8/Body length } \\
\text { D4-8/Body length }\end{array}$ & $0.347 \pm 0.020$ & $0.337 \pm 0.011$ & 0.001 & decrease \\
Depth of caudal peduncle/Body length & $0.096 \pm 0.009$ & $0.092 \pm 0.014$ & 0.048 & decrease \\
D4-7/Body length & $0.229 \pm 0.016$ & $0.241 \pm 0.022$ & 0.001 & decrease \\
\hline
\end{tabular}


(continued)

\begin{tabular}{lccccc}
\hline \multirow{2}{*}{ Character } & \multicolumn{2}{c}{ Mean values (cm) } & Value of P & Trend of change \\
\cline { 2 - 4 } & Cluster I & Cluster II & & \\
\hline D9-10/Body length & $0.171 \pm 0.015$ & $0.180 \pm 0.011$ & 0.001 & increase \\
D3-9/Body length & $0.272 \pm 0.012$ & $0.285 \pm 0.022$ & 0.000 & increase \\
Head depth/Body length & $0.883 \pm 0.042$ & $0.900 \pm 0.030$ & 0.015 & increase \\
Depth of head/Body length & $0.138 \pm 0.019$ & $0.146 \pm 0.019$ & 0.016 & increase \\
\hline
\end{tabular}

can also be divided into three clusters: 1- to 2-year-old cluster, 3- to 4-year-old cluster and 5-year-old cluster. However, the latter two clusters had smaller Euclidean distance, and high discrimination error rate, which suggest silver carps have greater body geometry changes between one and two years of age, while bighead have greater body geometric changes during two to three years of age. Changes in silver carp during $3-4$ years of age and in bighead during $4-5$ years of age may be associated with sexual maturity.

\subsection{Allometry of silver and bighead carp}

Clustering and discriminant analysis reveal that allometry occurs between 1 and 2 years of age in silver carps and between $2-3$ years of age in bighead carps. One way ANOVA results indicate ten meristic measurements, including body depth, head depth, snout, and eye diameter become significantly smaller during

\section{Reference:}

Axel M, 1990. Morphometrics and allometry in the trophically polymorphic cichlid fish, Cichlasoma citrinellum: Alternative adaptations and ontogenetic changes in shape [J]. J Zool, 221(2): 237-260.

Cao WX. 2008. Expert Forum: The Yangtza Valley water ecological environment and sustainable economic development -Several issues on the protection of fish resources in Yangtze River Basin [J]. Resour and Environ in the Yangtza Valley, 17(2): 163-164.

Chen DQ, Qiu SL, Huang MG, Liu SP. 1995. On the dynamic monitoring of fish resources in the Yangtze River [J]. Resour and Environ in the Yangtza Valley, 4(4): 303-307.

Ding SQ, Zhu GW, Wei Z, Wang Q, Wu CL. 2005. Study on the growth and development of Grass Carp, Silver Carp, Bighead Carp and Black Carp[J]. J Agric Sci, 33(9): 1660-1662.

Guo XG, Zhang YG, He SP. 2004. Morphological variations and species validity of genus Euchiloglanis (Siluriformes: Sisoridae) in china [J]. Acta Hydro Sin, 28(3): 260-268.

Huysentruyt F, Devaere S. 2009. Early development and allometric growth in the armoured catfish Corydoras aeneus [J]. Hydrobiologia, 627: 45-54.

John MC. 1990. Growth and relative size of calcified structures of fish[J]. Trans Am Fish Soc, 119(4): 673-688.

John R, Post E, Parkinson A. 2001. Energy allocation strategy in young fish: Allometry and survival[J]. Ecology, 82(4): 1040-1051.

Liu CX, Peng ZG, He SP. 2005. Studies on species classification for development between 1 year of age and 2 year of age in silver carps, while twelve measurements (e. g. caudal peduncle length; origin of caudal fin to (back of head), origin of pelvic fin, origin of anal fin) significantly increased. During bighead carp development from 2 to 3 years of age, twelve meristic measurements (e.g. body depth, head length, eye diameter) significantly decreased and five measurements (e.g. head depth, caudal peduncle length) significantly increased. In summary, among 30 analyzed measurements, 22 measurements for silver carp and 17 measurements for bighead carp showed allometric growth. Therefore, for back calculation of fish growth, allometric growth characters should be avoided. For identification of species, analysis of population differences and establishment of germplasm standards, it is necessary to sufficiently consider allometric growth in these species.

genus cranoglanis peters with the method of morphometrics $[\mathrm{J}]$. Acta Hydro Sin, 29(5): 507-512.

Liu HL, Chui H. 1992. A study on the bioloy of post-larval development of the filtering apparatus in bighead carp (Aristichthys nobilis) [J]. J Dalian Fish Univ, 7(1): 1-10.

Liu JK, Cao WX. 1992. Fish resources of the Yangtze River basin and the tactics for their conservation [J]. Resour and Environ in the Yangtza Valley, 1(1): 17-23.

Li SF, Li CH, Li JL. 1998. Analysis of morphological variations among strains of nile tilapia (Oreochromis niloticus)[J]. Acta Zool Sin, 44(4): 450-457.

Li SF, Lu GQ, Zhou BY. 1995. Feasibility studies on genetic conservation of Chinese carps in swan oxbow of the Yangtze River [J]. Resour and Environ in the Yangtza Valley, 19(3): 193-202.

Li SF, Wu LZ, Wang Q, Qiu QR, Chen YL. 1990. Genetical Characterization of Silver carp, Bighead carp and Grass carp in Yangtze River, Pearl River and Heilongjiang [M]. Shanghai: Shanghai Scientific \& Technical Publisher, 109-124.

Li SF, Zhou BY, Ni CK, Chen ZQ. 1989. Morphological variations of silver carp, bighead and grass carp from Changjiang, Zhujiang and Heilongjiang rivers [J]. Acta Zool Sin, 35(4): 390-398.

Li SF, Zhou BY, Lu GQ, Zhao JL. 1997. A study on the criteria and inspection of brooders of silver carp, bighead carp, grass carp and black carp originated from the Yangtze river[J]. J Fish China, 
21(2): 143-151.

Liu SP, Chen DQ, Duan XB,Qiu SL,Huang MG. 2004. Monitoring of the four famous Chinese carps resources in the middle and upper reaches of the Yangtze River [J]. Resour and Environ in the Yangtza Valley, 3(2): 183-186.

Liu SP, Chen DQ, Zhang JB, Qiu SL,Fan QX. 2002. Studies on the natural resources reservoir of the four major Chinese carps in Laojianghe oxbow[J]. Acta Hydro Sin, 26(6): 628-634.

Liu SP, Qiu SL, Chen DQ, Huang MG. 1997. Protection and rational utilization of the germplasm resources of the four major Chinese carps in the Yangtze river system [J]. Resour and Environ in the Yangtza Valley, 6(2): 128-130.

Lü YP . 2008. Comparisons of morphological characters in Hemibarbus labeo of 1-2 year-old and their correlations [J]. J Shanghai Fish Univ, 17(2): 170-174.

Lin ZJ, Liang PW. 2006. Morphological characteristics of larval and juvenile Polyspondylogobius sinensis[J]. Acta Zool Sin, 52(3): 585-590.

Osse JWM, van den Boogaar JGM. 1995. Fish larvae, development, allometric growth, and the aquatic environment.in: Mass rearing of juvenile fish. (Pittman K, Batty RS, Verreth J, eds.). ICES Marine Science Symposium[M]. 201. 21-34, Bergen, 1995.

Qi DL, Guo SC, Tang WJ, Yang J, Zhao XQ. 2006. Molecular systematics of morphologically similar fishes in the Schizothoracinae in Nanmenxia River, with implication for morphological convergent evolution[J]. Acta Zool Sin, 52(5): 862-870.

Qing N, Lv FY, Zhao J, Fan YM, Hong JW. 2007. Morphological variations and geographical differentiations of Pelteobagrus intermedius in different drainage systems from the coastal area of Western South China[J]. Zool Res, 28(2): 207-212.

Qiu SL, Liu SP, Huang MG, Chen DQ, Duan XW. 2002. Monitoring of spawning sites of four major Chinese carps in the middle section of Yangtze River[J]. Acta Hydro Sin, 26(6): 716-718.

Schofield PJ, Williams JD, Nico LD. 2005. Foreign Nonindigenous
Carps and Minnows (Cyprinidae) in the United States-A Guide to their Identification, Distribution, and Biology [M]. USGS Scientific Investigations Report 2005-5041, Denver, U.S.

Shan XJ, Cao L, Huang W, Dou SZ. 2009. Feeding, morphological changes and allometric growth during starvation in miiuy croaker larvae[J]. Environ Biol Fish, 86: 121-130.

Sun XM, Meng QW. 1992. Development and structure of the filter and digestive organs and their relations with the food habits in silver carp and bighead [J]. J Fish China, 16(3): 202-212.

Survey Team of Spawning Grounds of Domestic Fishes in Yangtze River. 1982. A survey on the spawning grounds of the "Four famous Chinese Carps" in the Yangtze river after dammed by the key water control project at Gezhouba [J]. J Fish China, 6(4): 287-304.

Wan RJ, Jiang YW, Zhuang ZM. 2004. Morphological and developmental characters at the early stages of the tonguefish Cynoglossus semilaevis[J]. Acta Zool Sin, 50(1): 91-102.

Wang XA, Ma AJ, Xu K, Lei JL, Yang Z, Qu JB. 2008. Relationship between morphometric attributes and body weight of juvenile turbots Scophthalmus maximus [J]. Acta Zool Sin, 54(3): 540-545.

Xie ZG, Xie CX, Zhang E. 2003. Morphological variations among the Chinese Species of Sinibrama (Pisces:Teleostei:Cyprinidae),with comments on their species validities [J]. Zool Res, 24(5): 321-330.

Yu HX, Tang WQ, Li SF. 2009. Growth character of silver carp at National Original Breeding Farm in Lake Laojianghe, middle reaches of the Yangtze River [J]. Chn J Zool, 44 (2) :21-27.

Yu JY, He XH. 2003. SPSS Statistical Data Analysis and Application [M]. Beijing: Posts \& Telecom Press, 251-310.

Zhang YT, Fang KT. 1982. Introduction to Multivariate Statistical Analysis[M]. Beijing: Science Press, 393-401.

Zhao J, Zhu XP, Chen YL, Liu YH, Chen YC, Zheng GM. 2007. Morphological variation of the ratmouth barbell Ptychidio jordani from different geographic populations in the Pearl River Basin [J]. Acta Zool Sin, 53(5): 921-927. 